Reprod. Nutr. Dévelop., 1986, 26 (2 A), 515-522.

\title{
Plasma concentrations of luteinizing hormone growth hormone, oestradiol, testosterone and androstenedione in the domestic hen from 6 weeks of age to sexual maturity
}

\author{
J. WILLIAMS, S. HARVEY $\left({ }^{*}\right)$
}

Station de Recherches Avicoles,

I.N.R.A., Nouzilly, 37380 Monnaie, France.

$\left(^{*}\right)$ The Wolfson Institute, The University of Hull, Hull, HU6 7RX, North Humberside, England.

Summary. The concentrations of luteinizing hormone (LH), growth hormone $(\mathrm{GH})$, oestradiol, testosterone and androstenedione were determined in weekly blood samples obtained from a group of female chickens. The study extended from 6 weeks of age to the sexual maturity of each animal. Clear increases in the concentrations of $\mathrm{LH}$ and the steroid hormones in plasma were found during the pre-pubertal period lasting from approximately 12 to 24 weeks of age, and these changes were consistent with previously reported observations on the development of the ovary during this period. The pattern of $\mathrm{GH}$ secretion appeared quite different as the concentrations of this hormone in plasma were high in the initial and final periods of observation, but low from approximately 9 to 23 weeks of age. Thus, the pre-pubertal period in the hen is characterized by increases in $\mathrm{LH}$ and steroid hormone secretion, but there is no sustained augmentation of GH secretion, making it unlikely that $\mathrm{GH}$ directly influences the rapid growth of ovarian tissue during this period.

\section{Introduction.}

Many studies have been published of the changes of the concentrations of luteinizing hormone $(\mathrm{LH})$ and sex steroids in the plasma of female chickens during sexual maturation. Most studies have been concerned with one or two hormones with the exception of that of Tanabe et al. (1981) who measured luteinizing hormone, progesterone, oestradiol and testosterone by radioimmunoassay. As this study covered the period from 28 to 1141 days of age, it is difficult to discern the relationships between these hormones during the period of sexual maturation.

The study reported below was conducted to study the period from 6 to 25 weeks more intensively and included weekly estimations of LH, oestradiol, testosterone in peripheral plasma as well as other measurements. These were : Growth Hormone $(\mathrm{GH})$ and androstenedione. The first has been studied pre- 
viously in growing hens (Harvey et al,, 1979) but not in association with LH and the sex steroids, while study of androstenedione is novel and of interest with respect to the changes in steroidogenesis which occur prior to the onset of egglaying.

\section{Materials and methods.}

\section{(i) Animals and blood samples.}

The animals were chosen at random from a flock of 300 birds of an experimental laying strain (I.N.R.A., Nouzilly, France) raised in a floor pen and allowed free access to water and food (soya, maize and wheat diet ; $11.7 \mathrm{MJ} / \mathrm{kg} ; 14 \%$ protein). $8 \mathrm{hrs}$ of artificial light per day were provided initially, and this amount was increased by $1 \mathrm{~h}$ per week at 16 weeks of age to a maximum of $16 \mathrm{hrs}$ light per day at 24 weeks of age. Hens were placed in individual cages from 20 weeks onwards.

The study commenced at 6 weeks of age with a group of 10 birds and a further 10 birds were added at 11 weeks of age. Blood samples of $10 \mathrm{ml}$ were collected via brachial venepuncture in a heparinized syringue and decanted into icecold tubes. Plasma was separated by centrifugation and stored at $-20^{\circ} \mathrm{C}$ until required for assays. The mean time of blood collection was approximately $11.00 \mathrm{am}$, that is, about $3 \mathrm{hrs}$ after the lights came on. Samples were collected every week and were continued for one week after each hen had laid its first egg.

(ii) Hormone assays of plasma samples.

LH: The method of Follett, Scanes and Cunningham (1972) was employed. 100 and $50 \mu \mathrm{l}$ samples were assayed in duplicate using fraction AE1 as labelled hormone and standard and an antiserum (15/8) raised against fraction CM2.

GH : $100 \mu$ samples were assayed according to the method of Harvey and Scanes (1977).

Oestradiol: $600 \mu \mathrm{l}$ of plasma were extracted and assayed according to the method of Etches, Williams and Rzasa (1984).

Androstenedione : $600 \mu \mathrm{l}$ samples were extracted and assayed according to the method of Williams and de Reviers (1981).

Testosterone : $600 \mu \mathrm{l}$ samples were extracted and assayed according to the method of Driot, de Reviers and Williams (1979) using the antiserum described by Caraty et al. (1981).

The androgen assays were validated for immature and laying hen plasma by adding increasing amounts of the authentic steroid (Sigma Chemical Co., St Louis, Missouri, USA) to pools of plasma. In both cases, the results of the regression analysis of steroid measured on steroid added showed that the slope of the fitted line was not significantly different from 1.0 ( $P<0.01$; Student's $t$-test). Within-assay coefficients of variation ranged from $7,8 \%$ to $18,6 \%$ while the range for between-assay variation was $12,1 \%$ to $25,2 \%$. 
(iii) Statistical analyses.

Data were analysed by ANOVA using an unbalanced incomplete block design; calculations were performed according to the general linear model approach (Kendall and Stewart, 1946) and Scheffe's 's' test was employed to detect differences between means.

\section{Results.}

LH, oestradiol, testosterone and androstenedione plasma levels. - (Table 1$)$. The changes in the concentrations of these four hormones in the plasma showed certain similarities. Titres observed in the juvenile bird were lower than those observed in adults in all cases, and a prolonged increase was observed week by week in the period preceeding the onset of egg-laying, which occurred at $24.9 \pm 1.3$ weeks (mean \pm s.d.). This change was most gradual in the case of

\section{TABLE 1}

Mean concentration ( \pm SEM) of $L H$, oestradiol, testosterone, androstenedione and $\mathrm{GH}$ in the plasma during sexual maturation in the female chicken.

\begin{tabular}{|c|c|c|c|c|c|}
\hline \multirow{2}{*}{$\begin{array}{c}\text { Age } \\
\text { (weeks) }\end{array}$} & \multicolumn{5}{|c|}{ Compound } \\
\hline & $\begin{array}{c}\mathrm{LH} \\
(\mathrm{ng} / \mathrm{ml})\end{array}$ & $\begin{array}{l}\text { Oestradiol } \\
(\mathrm{pg} / \mathrm{ml})\end{array}$ & $\begin{array}{l}\text { Testosterone } \\
(\mathrm{pg} / \mathrm{ml})\end{array}$ & $\begin{array}{l}\text { Androstenedione }\left({ }^{1}\right) \\
(\mathrm{pg} / \mathrm{ml})\end{array}$ & $\begin{array}{c}\mathrm{GH} \\
(\mathrm{ng} / \mathrm{ml})\end{array}$ \\
\hline 6 & $2.02 \pm 0.19$ & $37 \pm 8(3)$ & $51 \pm 5$ & $98 \pm 20$ & $11.3 \pm 4.3$ \\
\hline 7 & $1.81 \pm 0.21$ & $26 \pm 5(4)$ & $41 \pm 10$ & $51 \pm 12$ & $6.5 \pm 1.0$ \\
\hline 8 & $2.09 \pm 0.26$ & $60 \pm 5(4)$ & $59 \pm 12$ & $83 \pm$ & $18.7 \pm 5.0$ \\
\hline 9 & $1.75 \pm 0.27$ & $35 \pm 9(4)$ & $48 \pm 7$ & $57 \pm$ & $5.7 \pm 1.0$ \\
\hline 10 & $1.76 \pm 0.23$ & $31+4(4)$ & $48 \pm 6$ & $130 \pm$ & $3.5 \pm 0.4$ \\
\hline 11 & $2.17 \pm 0.27$ & $60 \pm 4(8)$ & $47 \pm 6$ & $112 \pm 34$ & $3.3 \pm 0.3$ \\
\hline 12 & $2.09 \pm 0.17$ & $60 \pm 8(7)$ & $44 \pm 8$ & $94 \pm$ & $3.4 \pm 0.4$ \\
\hline 13 & $2.39 \pm 0.21$ & $53 \pm 8(7)$ & $49 \pm 9$ & $143 \pm$ & $2.7 \pm 0.3$ \\
\hline 14 & $2.21 \pm 0.15$ & $84 \pm 10(9)$ & $49 \pm$ & $183 \pm$ & $6.8 \pm 0.7$ \\
\hline 15 & $2.96 \pm 0.30$ & $137 \pm 20(9)$ & $63 \pm$ & $152 \pm$ & $7.1 \pm 0.4$ \\
\hline 16 & $2.75 \pm 0.21$ & $164 \pm 28(9)$ & $79 \pm 7$ & $207 \pm$ & $4.0 \pm 0.6$ \\
\hline 17 & $2.38+0.19$ & $139 \pm 19(9)$ & $69 \pm 7$ & $218 \pm 91$ & $4.0 \pm 0.3$ \\
\hline 18 & $2.50 \pm 0.19$ & $121 \pm 22(9)$ & $83 \pm 11$ & $252 \pm 88$ & $3.0 \pm 0.4$ \\
\hline 19 & $2.62 \pm 0.27$ & $142 \pm 35(9)$ & $71 \pm 12$ & $296 \pm 113$ & $2.7 \pm 0.3$ \\
\hline 20 & $2.51 \pm 0.24$ & $157 \pm 26(9)$ & $89 \pm 11$ & $279 \pm 92$ & $3.1 \pm 0.3$ \\
\hline 21 & $2.83 \pm 0.28$ & $192 \pm 31(9)$ & $100 \pm 13$ & $287 \pm 114$ & $3.9 \pm 0.5$ \\
\hline 22 & $3.03 \pm 0.23$ & $269 \pm 39(9)$ & $85 \pm 8$ & $206 \pm 50$ & $2.6 \pm 0.2$ \\
\hline 23 & $3.38 \pm 0.22$ & $364 \pm 52(9)$ & $95 \pm 9$ & $358 \pm$ & $6.3 \pm 1.4$ \\
\hline 24 & $3.03 \pm 0.23$ & $271 \pm 43(9)$ & $108 \pm 10$ & $326 \pm$ & $6.0 \pm 0.7$ \\
\hline 25 & $3.13 \pm 0.25$ & $327 \pm 28(9)$ & $102 \pm 10$ & $361 \pm 56$ & $17.4 \pm 5.0$ \\
\hline \multicolumn{6}{|c|}{ Results of age effect in ANOVA } \\
\hline $\mathrm{F}$ & 3.73 & 11.54 & 5.66 & 3.53 & 6.39 \\
\hline $\mathrm{P}$ & 0.005 & 0.005 & 0.005 & 0.005 & 0.005 \\
\hline
\end{tabular}

$\mathrm{n}=10$ (weeks $6-10$ ), $\mathrm{n}=20$ (weeks 11-25) unless otherwise indicated by figures in parentheses.

(1) values transformed to $\log (x+1)$ for ANOVA. 
LH. Between 12 and 22 weeks of age, the levels of this hormone in the plasma increased by approximately $50 \%$. There was one other isolated transient peak at 8 weeks of age. The changes in testosterone in the plasma were of slightly greater magnitude (around $100 \%$ ) but the increase appeared to occur later as all values recorded in birds aged 14 weeks or less were significantly different $(P<0.05)$ from those in birds aged 24 weeks or more. With respect to androstenedione, the increase in mean plasma levels was of the order of $350 \%$, but it was more difficult to locate precisely as there was more variation in the data. However, the mean values at $7,8,9$ and 12 weeks were significantly lower than the levels found from 23 weeks onwards. Plasma androstenedione concentrations tended to be higher than those of testosterone, and this tendency became clearer as the birds approached sexual maturity. The most clear-cut pre-pubertal increase was found for oestradiol. Levels remained unchanged from 6 to 13 weeks then rose sharply. The levels from 21 weeks onwards were significantly higher $(\mathrm{P}<0.05)$, by approximately $450 \%$, than those in the young bird.

Growth hormone. - The initial and the final concentrations in the plasma tended to be higher but, due to the variation in the data, significant peaks $(P<0.05)$ were found only at 8 and 25 weeks of age. An apparent peak was located from weeks 14 to 15 but no significant change was found at this time.

Onset of sexual maturity. - The mean age at the first egg was $24.9 \pm 1.3$ (mean \pm s.d.) weeks. This diversity of ages at sexual maturity may be held to distort the means of data arranged chronologically, hence these means are shown together with those calculated for the five weeks preceeding each hen's first egg (table 2). Although detail differences are apparent, the overall trends in plasma hormone concentrations are the same irrespective of the time scale employed.

\section{Discussion.}

Of all the compounds reported on here whose concentrations in the plasma have been measured in the growing hen, $\mathrm{LH}$ is perhaps the most widely studied to date. The changes in the pattern of the secretion of this hormone reported here agree well with the reports of Wilson (1978) and Tanabe et al. (1981), while Sharp (1975) and Williams and Sharp (1977) reported a marked decrease just before the onset of egg-laying but this was not found in the present investigation. Additionally, the values reported here are low compared to other investigations, but these differences may be accounted for by the different ways birds were housed, handled and sampled, or strain differences. The latter has been studied by Scanes et al. (1980) and by Williams (1977) and its appears that both the level and the pattern of changes of LH in the plasma of growing female chicks can vary with the strain. Blood samples for this study were taken in the morning and the possibility therefore arises that the failure to find a fall in plasma levels of LH in point of lay pullets was due to samples being taken at the time of day when pre-ovulatory surges of this hormone occur.

The concentrations of $\mathrm{GH}$ in the plasma of immature birds (6-20 weeks) followed a similar pattern of changes to those reported by Harvey et al. (1979) and 


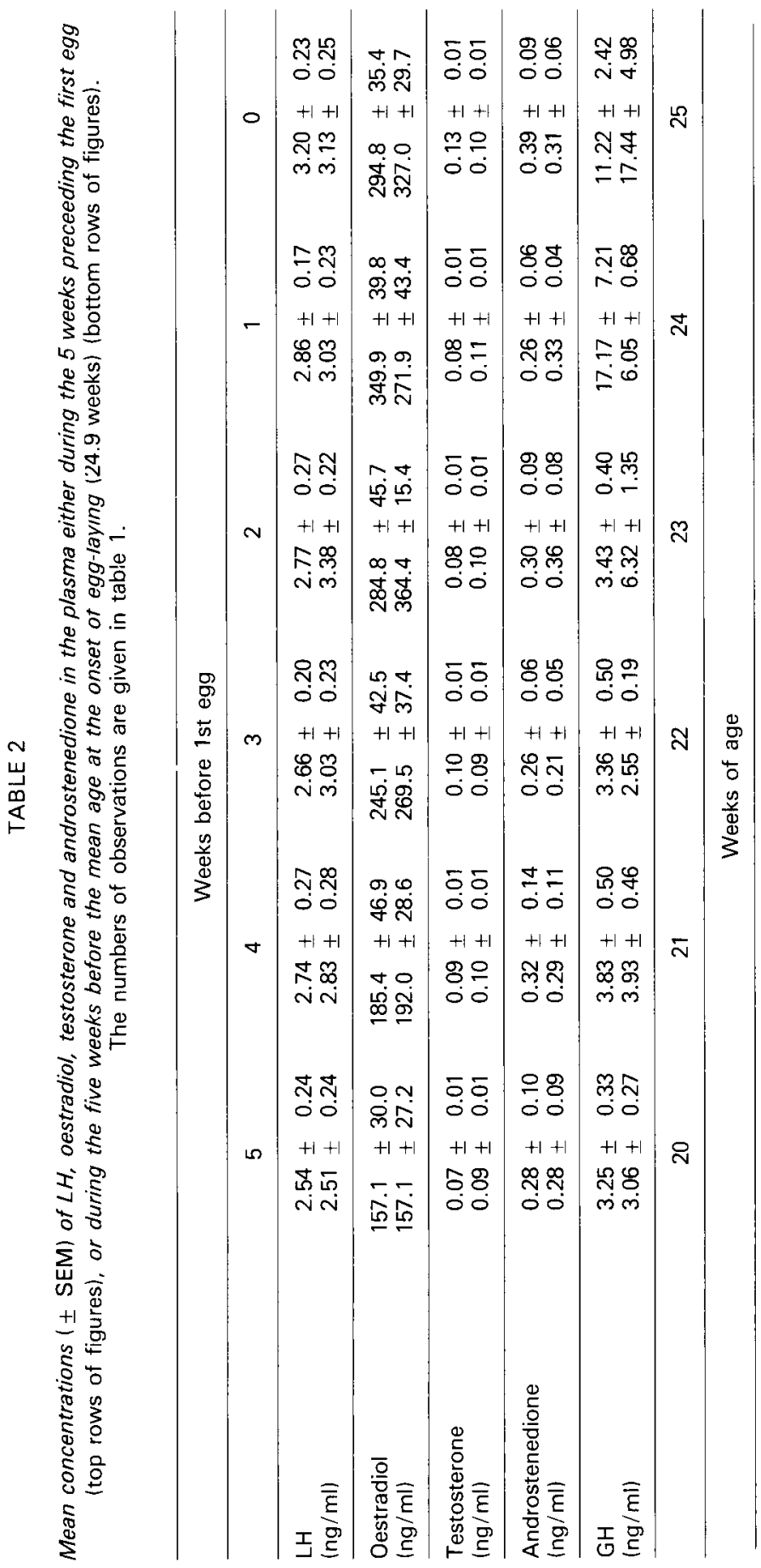


Scanes et al. (1980) but the increase found here as the birds came into lay is novel. The other noteworthy feature of the $\mathrm{GH}$ data is the low levels found overall although control plasma analysed in the same assay returned higher values in keeping with the majority of previous observations. A possible explanation for the point of lay increase in plasma $\mathrm{GH}$ is the time of day at which blood was withdrawn. The low values may be a reflection of a strain difference such as that reported by Scanes et al. (1980) or possibly of the technique of collecting blood into ice-cold tubes. The concentrations of $\mathrm{GH}$ in the plasma of point of lay hens are, however, similar or even higher than previously reported values (Harvey, Scanes and Sharp, 1979 ; Bedrak, Harvey and Chadwick, 1981).

The data presented here for the steroid hormones oestradiol and testosterone do not display any major departures from the profiles described by Tanabe et al. (1981). However, Senior (1974) found that the pre-pubertal oestradiol increase was followed by a decline during the three weeks before the first egg was laid, but emphasized that variation between individuals was considerable. The results for these steroid hormones and those for androstenedione are consistent with the hypothesis of a progressive increase in the steroidogenic processes of the ovary during sexual maturation. It has been shown previously (Wilson and Sharp, 1975) that the ovary increases in weight one hundredfold in the 9 weeks before sexual maturation while body weight increases only by a factor of 1.75 . The timing of the increases in the concentrations of steroid hormones in the plasma for the present data is consistent with this time-scale of ovarian development. A previous report (Williams and Sharp, 1977) suggests that progesterone is one exception to this temporal pattern of changes of steroid hormone concentrations in the blood of growing chickens. The titres of progesterone in plasma increase just prior to the first egg, and this is consistent with other evidence showing that this hormone is chiefly secreted by follicles at or close to maturation and ovulation (Etches, Croze and Duke, 1981). As plasma growth hormone levels remain low during prepubertal ovarian development, it appears unlikely that $\mathrm{GH}$ stimulates the rapid growth of ovarian tissue.

Reçu en novembre 1985.

Accepté en décembre 1985.

Acknowledgements. - The expert technical assistance of Mesdames M.-T. Durand, M. Garreau-Mills and Monsieur G. Guy is gratefully acknowledged. Drs P. J. Sharp and F. J. Cunningham are thanked for materials used in the LH assay.

Résumé. Evolution des concentrations plasmatiques de l'hormone lutéinisante et des stérö̈des sexuels chez la poule entre 6 semaines d'âge et la maturité sexuelle.

Nous avons mesuré la concentration dans le sang de l'hormone lutéotrope (LH), de l'hormone de croissance $(\mathrm{GH})$, de l'œstradiol, de la testostérone et de l'androstènedione sur un lot de poulettes en croissance. Les prélèvements hebdomadaires ont été réalisés de l'âge de 6 semaines à la maturité sexuelle pour chaque individu. Nous avons observé une augmentation nette de la concentration plasmatique de $\mathrm{LH}$ et des stéroïdes sexuels avec la maturité sexuelle, au cours d'une période de 12 à 24 semaines d'âge environ. Cette modification est en accord avec les résultats connus de la croissance de l'ovaire au cours de cette 
phase. La secrétion de $\mathrm{GH}$ semble évoluer différemment car sa concentration dans le plasma est élevée dans les premiers et derniers prélèvements de l'essai mais elle reste à un bas niveau de la $9^{\mathrm{e}}$ à la $23^{\mathrm{e}}$ semaine d'âge. Au cours de la période précédant la maturité sexuelle, il y a donc une augmentation de la secrétion de $\mathrm{LH}$ et des stéroïdes sexuels mais pas de variation de la sécrétion de $\mathrm{GH}$. Nous concluons que la $\mathrm{GH}$ n'est probablement pas impliquée dans le contrôle de la croissance rapide des tissus ovariens observée durant cette phase.

\section{References}

BEDRAK E., HARVEY S., CHADWICK A., 1981. Concentrations of pituitary, gonadal and adrenal hormones in serum of laying and broody white rock hens. J. Endocrinol., 89, 197-204.

CARATY A., de REVIERS M.-M., MARTINAT N., BLANC M., 1981. A reinvestigation of hypothalamic-pituitary interactions : simultaneous changes in tissue and plasma levels of gonadotrophins, prolactin, testosterone and hypothalamic LH-RH after bilateral orchidectomy and cryptorchidism. Reprod. Nutr. Dévelop., 21, 455-465.

DRIOT F. J. M., de REVIERS M., WILLIAMS J., 1979. Plasma testosterone levels in intact and hemicastrated growing cockerels. J. Endocrinol, 81, 169-174.

ETCHES R. J., CROZE F., DUKE C. E., 1981. Plasma concentrations of luteinizing hormone, progesterone, testosterone and oestradiol in follicular and peripheral plasma during the ovulation cycle of the hen. Adv, physiol. Sci., 33, 89-98.

ETCHES R. J., RZASA J., WILLIAMS J., 1984. The effects of corticosterone and dietary changes in the hen on ovarian function, plasma LH and steroids and the response to exogenous LHRH. J. Reprod. Fert., 70, 121-130.

FOLLETT B. K., SCANES C. G., CUNNINGHAM F. J., 1972. A radioimmunoassay for avian luteinizirig hormone. J. Endocrinol., 52, 359-378.

HARVEY S., SCANES C. G., 1977. Purification and radioimmunoassay of chicken growth hormone. J. Endocrinol., 73, 321-329.

HARVEY S., SCANES C. G., CHADWICK A., BOLTON N. J., 1979. Growth hormone and prolactin secretion in growing domestic fowl : influence of sex and breed. Brit. Poult. Sci, 20, 9-17.

HARVEY S., SCANES C. G., SHARP P. J., 1979. Variations in plasma growth hormone concentrations in laying hens. Brit. Poult. Sci, 20, 163-166.

KENDALL M. G., STEWART A., 1946. The advanced theory of statistics, Vol. II, Griffin, London.

SCANES C. G., VAN MIDDELKOOP J. H., SHARP P. J., HARVEY S., 1980. Strain differences in the blood concentrations of luteinizing hormone, prolactin and growth hormone in female chickens. Poult. Sci., 59, 159-163.

SENIOR B. E., 1974. Oestradiol concentration in the peripheral plasma of the domestic hen from 7 weeks of age until the time of sexual maturity. J. Re rrod. Fert., 41, 107-112.

SHARP P. J., 1975. A comparison of variations in plasma luteinizing hormone concentrations in male and female domestic chickens (Gallus domesticus) from hatch to sexual maturity. $J$. Endocrinol., 67, 211-223.

TANABE Y., NAKAMURA T., TANASE H., DOI O., 1981. Comparisons of plasma LH, progesterone, testosterone and estradiol concentrations in male and female chickens /Gallus domesticus) from 28 to 1141 days of ages. Endocrinol, jap., 28, 605-613.

WILSON S. C., 1978. Relationship between plasma concentration of luteinising hormone and intensity of lay in the domestic hen. Brit. Poult. Sci., 19, 643-650.

WILSON S. C., SHARP P. J., 1975. Effects of progesterone and synthetic luteinizing hormone releasing hormone on the release of luteinizing hormone during sexual maturation in the hen (Gallus domesticus). J. Endocrinol., 67, 359-369.

WILLIAMS J. B., 1977. The endocrine control of egg production in poultry. Ph. D. Thesis, Univ. Edinburgh. 
WILLIAMS J., de REVIERS M., 1981. Variations in the plasma levels of luteinizing hormone and androstenedione and their relationship with the adult daily sperm output in cockerels raised under different photoschedules. Reprod. Nutr. Dévelop., 21, 1125-1135.

WILLIAMS J. B., SHARP P. J., 1977. A comparison of plasma progesterone and luteinizing hormone in growing hens from eight weeks of age to sexual maturity. J. Endocrinol., 75 , 447-448.

Le Directeur de la publication : G. DUBOIS

Jouve, 18, rue Saint-Denis, 75001 Paris.

Dépôt légal : Avril 1986. No d'impression : 34839

CCPAP $n^{\circ} 1147$ ADEP 